\title{
Polska etyka lekarska przed powstaniem Akademii Krakowskiej (Wincenty Kadłubek, Witelo, Tomasz z Wrocławia)
}

Kontynuacja ogólnoeuropejskich idei etycznych

Ponieważ aż do powstania Akademii Krakowskiej szkolnictwo polskie nie dysponowało żadną placówką uniwersytecką, jednostki żądne szerszego wykształcenia musiały podejmować zagraniczne wyprawy naukowe. Wziąwszy pod uwagę uniwersalizm kulturowy Europy zachodniej, jak również fakt ustawicznego wzrostu liczby uniwersytetów ${ }^{1}$, podróże owe nie napotykały żadnych istotnych trudności. Najczęściej były to migracje na uczelnie francuskie lub włoskie ${ }^{2}$. Studia w Paryżu podejmowały między innymi takie postacie zasłużone dla kultury polskiej, jak Wincenty Kadłubek ${ }^{3}$, biskup Iwo Odrowąż (zm. 1229) (dwukrotnie przebywał w Paryżu - w 1198 i na przełomie lat 1216/1217) oraz jeden z najwybitniejszych uczonych polskiego średniowiecza, Ślązak Witelon (1230/1235-1275/1292). Z kręgu osób zdoby-

${ }^{1}$ Zob. szerzej: J. Le Goff, Inteligencja w wiekach średnich, przeł. E. Bąkowska, Warszawa 1966, s. $178,191-194$.

${ }^{2} \mathrm{O}$ innych kierunkach wypraw naukowych Polaków, zob. H. Barycz, Z dziejów polskich wędrówek naukowych za granicę, Wrocław - Warszawa - Kraków 1969, s. 7-199.

${ }^{3}$ Kwestia miejsca studiów W. Kadłubka nie jest rozstrzygnięta, zob. Mistrz Wincenty Kadłubek, przeł. i oprac. B. Kürbis, Wstęp, s. XXIII-XXV. 
wających wiedzę w Montpellier należy przypomnieć Tomasza z Wrocławia (1297-1378), Jana z Grotkowa i Jana Radlicę, który w okresie 1382-1392 piastował godność biskupa krakowskiego. Z kolei wśród studentów uczelni włoskich spotykamy takie osoby: jak Mikołaja z Polski (ok. 1235-1290), Stefana Pollaka (zm. 1319), Jana Bogorię Skotnickiego czy syndyka Uniwersytetu w Bolonii z 1321 roku4 .

Znaczną część wyjeżdżających stanowiły osoby pragnące zdobyć wykształcenie medyczne. Brak źródeł z XIII stulecia uniemożliwia jednak dokładne prześledzenie ich losów, a szczególnie tego, czy wszyscy oni wracali do kraju. Jeśli idzie o poświadczony pobyt na ziemiach polskich, można mówić o grupie około 25 lekarzy, z których większość, bo 13 przebywała we Wrocławiu. Reszta prowadziła praktyki w Krakowie i Poznaniu. W tym ostatnim mieście poświadczono pobyt najstarszego znanego nam $\mathrm{z}$ imienia lekarza, którym był Wilhelm, kanonik poznański, wymieniany w dokumentach pochodzących z 1228 roku $^{5}$.

Fakt, że tak wielu lekarzy żyło i praktykowało we Wrocławiu, sprawił, iż władze tego miasta, wzorując się na ustawach króla Rogera i cesarza Fryderyka, wprowadziły zasady uprawniające do świadczenia usług medycznych. Określono je w Statutach physicorum, apothecariorum et medicorum, które zostały spisane w 1352 roku i jak wynika z przytoczonego tytułu odnosiły się również do aptekarzy oraz cyrulików. Zgodnie z zawartymi w tych ustawach wymogami, lekarz winien posiadać wykształcenie uniwersyteckie w zakresie medycyny, a prawo do wykonywania praktyki nabywał $\mathrm{z}$ chwilą jego zaprzysiężenia przed radą miejską . Tą drogą usiłowano zablokować moż-

${ }^{4}$ A. Brückner, Dzieje kultury polskiej, t. 1: Od czasów prehistorycznych do r. 1506, Warszawa 1957, s. 281, 282; także P. Czartoryski, Średniowiecze, [w:] Historia nauki, red. B. Suchodolski, s. 37-40; brak dokładnej datacji wynika z faktu, że w średniowieczu nie prowadzono ksiąg metrykalnych, aby więc daną osobę umieścić w czasie, podaje się te elementy jej życiorysu, które zostały odnotowane w różnych zapiskach historycznych; temat metryk, zob. szerzej J. Kurpas, Początki ksiagg metrykalnych, Archiwa, Biblioteki i Muzea Kościelne, t. 2, z. 1-2, Lublin 1961, s. 5-42.

${ }^{5}$ J. Janikowski, Historia medycyny, s. 153; M. Łyskanowski, Skrypt z historii medycyny polskiej dla studentów I i II WL, oddziału stomatologicznego oraz doktorantów wszystkich specjalności, Warszawa 2000, s. 4 podaje, że był nim Jan Smer, ale to czysta spekulacja, zob. szerzej: Zbiór wiadomości do historyi sztuki lekarskiej w Polsce od czasów najdawniejszych, aż do najnowszych przez Ludwika Gąsiorowskiego, Dr Med. i Chir., t. 1, Poznań 1839, s. 51-53.

${ }^{6} \mathrm{~J}$. Gilewska-Dubis, Etos zawodu lekarza $w$ relacji $z$ pacjentem $w$ średniowiecznej medycynie europejskiej, [w:] Relacje lekarz - pacjent $w$ aspekcie społecznym, historycznym i kulturowym, red. B. Płonka-Syroka, Studia z Dziejów Kultury Medycznej, t. 10, Wrocław 2005, s. 80. 
liwość wejścia do stanu lekarskiego osobom nieuprawnionym (podobne zabezpieczenia spotykamy w przytoczonych ustawach Rogera i cesarza Fryderyka). Dla rajców Wrocławia bardzo ważny był więc fakt, aby lekarz w swym zawodzie prezentował pełny profesjonalizm.

W XIV wieku liczba działających w Polsce lekarzy z wykształceniem akademickim nieznacznie wzrosła, dochodząc do 33 osób. Większość z nich, bo 19 skupiało się w Krakowie, reszta praktykowała w Raciborzu, Brzegu, Wrocławiu, Włocławku i Poznaniu. Wykształcenie wymienionych medyków nie było równomierne. $\mathrm{Z}$ przywołanej liczby jedynie pięciu posiadało tytuł doktora medycyny, dziewięciu było magistrami, a reszta bakałarzami. Do osób z tytułami doktorskimi należeli: Ajmeryk promowany w 1307 roku w Padwie przez Piotra z Abano; Dominik promowany w Bolonii w 1363 r.; Monald z Krakowa, notowany w aktach z 1397 r. jako "egregius docktor”; Olszkowski z pierwszej połowy XIV wieku i Jan Radlica promowany w Montpellier, w 1370 roku? $^{7}$.

W świetle zaprezentowanych faktów można założyć, że niezależnie od przyswajanych przez władze Wrocławia zachodnich wzorów moralnych i jurystycznych, źródeł polskiej etyki lekarskiej należy doszukiwać się przede wszystkim w poglądach lekarzy wracających z zagranicznych studiów medycznych, nie ma bowiem wątpliwości, że wraz z wiedzą przedmiotową, poznawali oni również związane $z$ nią wzorce postaw moralnych oraz że te wzorce zaszczepiali następnie na naszym gruncie. W tym upowszechnianiu kultury etycznej partycypowali również uczeni innych specjalności, jak również dostojnicy państwowi i kościelni, którzy z powodu sprawowanych urzędów utrzymywali żywe kontakty z kulturą zachodu.

Do wspomnianego kręgu zaliczyć można Wincentego Kadłubka, Witelona i Tomasza z Wrocławia, którym należałoby tu poświęcić nieco więcej uwagi.

\section{Mistrz Wincenty Kadłubek}

Urodził się w Kargowie (lub Karwowie) w 1150 lub 1160 roku, a zmarł 8 marca (4 kwietnia) 1223 roku. Był synem Bogusława ze szla-

\footnotetext{
${ }^{7}$ A. Bednarski, Materiały do dziejów medycyny polskiej w XIV i XV stuleciu, Kraków 1939, s. 4 [28], 5 [29]; J. Jankowski podaje przybliżone dane, podkreślając równocześnie rolę Wrocławia jako drugiego, po Krakowie, skupiska lekarzy, zob. Historia medycyny, s. 155-157; z kolei J. Rostafiński dla XIII i XIV wieku podaje łącznie liczbę 42 lekarzy, Medycyna na Uniwersytecie Jagiellońskim w XV wieku przez Józefa Rostafińskiego, Kraków 1900, s. 19.
} 
checkiego rodu Łabędziów ${ }^{8}$, chociaż niektórzy uważają, że przydomek „Kadłub" wskazuje na chłopskie pochodzenie, sugerując, iż chodzi o powszechnie używane wśród chłopów przezwisko wywodzące się od słowa „kadłub” oznaczającego wydrążony pień drzewa' ${ }^{9}$. Tytuł mistrza (łac. magister) zdobył Kadłubek studiując w Paryżu lub Bolonii nauki wyzwolone i prawo, jest też możliwe, że przypisano go jemu $\mathrm{z}$ racji pełnienia funkcji nauczycielskiej w Szkole Katedralnej w Krakowie ${ }^{10}$. Od roku 1208, przez 10 lat, pełnił godność biskupa krakowskiego, powołany na to stanowisko bullą papieża Innocentego III datowaną na dzień 28 marca $1208 \mathrm{roku}^{11}$. Brał aktywny udział w kilku zjazdach kościelnych: w Borzykowie (1210 r.), w Mstowie i Mąkolnie (1212 r.) oraz w Wolborzu (1214 r.). Uczestniczył też w IV Soborze Laterańskim, który odbył się w 1215 roku $^{12}$. W roku 1218 ustąpił z biskupstwa i wstąpił do zakonu cystersów w Jędrzejowie, gdzie też zmarł ${ }^{13}$. Dnia 18 lutego 1764 roku został beatyfikowany przez papieża Klemensa XIII ${ }^{14}$. Jego szczątki przeniesiono wówczas do Katedry Królewskiej na Wawelu, gdzie spoczywają do dzisiaj w kaplicy biskupa Piotra Tomickiego ${ }^{15}$.

Mistrz Wincenty jest autorem Kroniki Polski, obejmującej jej dzieje od czasów pradawnych po 1202 rok. W tle stanowiącej treść dzieła prezentacji faktów i pseudofaktów historycznych przedstawia on szereg refleksji z zakresu filozofii moralnej, w ramach których, pomimo braku wykształcenia lekarskiego, porusza pewne wątki z zakresu etyki medycznej. I tak na przykład zaleca, aby każdą bez wyjątku chorobę leczyć w możliwie wczesnym stadium. Lekarz powinien przy tym zapoznać się ze źródłem schorzenia i z wiedzy tej zaczerpnąć wskazówki dotyczące sposobu samej terapii. Zastosowane metody nie mogą powodować gorszych objawów aniżeli sama choroba, dotyczy to szczególnie leczenia $\operatorname{ran}^{16}$. I tu, cytując dokładnie Mistrza, pierwszeństwo w zakresie terapii należy oddać naturze, która leczy

\footnotetext{
${ }^{8}$ Mistrz Wincenty Kadłubek, przeł. i oprac. B. Kürbis, Wstęp, s. XII, XVI, LV.

${ }^{9}$ Tamże, s. IX.

${ }^{10}$ Tamże, s. XXI-XXV.

${ }^{11}$ Tamże, s. XXXVII-XXXIX.

${ }^{12}$ Tamże, s. XLI.

${ }^{13}$ Tamże, s. LV.

${ }^{14}$ Tamże, s. LVIII.

15 Internet, http://pl.wikipedia.org/wiki/Kronika Wincentego-Kadłubka [dostęp 9 czerwca 2010].

${ }^{16}$ J. Lachs, Wiadomości lekarskie w Kronice Kadłubka, [w:] Prace Komisji Historii Medycyny i Nauk

Przyrodniczo-Matematycznych, Kraków 1939, s. 14 [122], 15 [123].
} 
je sama, bez niczyjej pomocy ${ }^{17}$. Obowiązkiem lekarza jest jednak, by ranę odsłonił, umożliwiając jej zbadanie.

Postawę medyka określa Mistrz następująco:

Lecz lekarzowi nie zawsze się udaje chorego wyleczyć (medicus non semper sanabit) [...] czasem nawet i szkodę przynosi, i nic łatwiejszego, jak pod jego okiem ducha wyzionąć (nihil facilius, quam sub medici specie animam aegrotantis excludere), [...] trucizna bowiem w jego ręku może stać się czasem nawet szkodliwa. [jak] miecz w ręku obłąkanego (consilium in suadua iniqui est toxicum in pyxide medicantis [...] gladius in manu furiosi $)^{18}$.

Mistrz Wincenty docenia również psychiczne oddziaływanie osoby lekarza na pacjenta. Żąda, by swoim wesołym usposobieniem wpływał on na samopoczucie chorego, czyli lecząc równocześnie rozweselał (praesertim cum hilaritate medentis aeger nonnunquam hilarescat $)^{19}$.

Oryginalne, ale zgodne $\mathrm{z}$ duchem epoki, są zalecenia dotyczące leczenia bezpłodności. Ilustruje je przykładem dolegliwości księżnej Judyty, podkreślając istotną w takim wypadku rolę modlitwy. Kiedy mąż Judyty wysłał posłów do klasztoru św. Idziego w St. Gilles, aby w intencji przywrócenia jej płodności zakonnicy zanosili modły do Boga - czytamy w Kronice - praktyka taka okazała się skuteczna i niebawem księżna urodziła syna, późniejszego władcę Bolesława Krzywoustego ${ }^{20}$.

Analizując powyższe pouczenia, nietrudno dostrzec, jakim wzorcom postaw lekarzy hołdował ich autor. Medycy powinni podejmować swe działania bezzwłocznie, ale po uprzednim zapoznaniu się ze źródłem choroby i przy uwzględnieniu leczniczej mocy natury. Kadłubek podkreśla, że lekarza winien cechować pragmatyzm, czyli umiejętność wyciągania wniosków z zaistniałej sytuacji. Zaleca też ostrożność i rozwagę w leczeniu, zaznaczając, że podjęte kroki nie mogą powodować większych szkód aniżeli sama choroba. Interesuje go też stosunek lekarza do pacjenta, której to relacji przypisuje możność pozytywnego oddziaływania wzmacniającego proces leczenia. Zgodnie z duchem medycyny średniowiecznej, panaceum na niektóre ludzkie niedomogi upatrywał również w czynnikach nadprzyrodzonych. Reasumując: Wincenty Kadłubek chciałby widzieć w lekarzu osobę kompetentną,

\footnotetext{
17 Tamże, s. 8 [116].

${ }^{18}$ Tamże, s. 15 [123].

19 Tamże, s. 14 [122].

${ }^{20}$ Tamże, s. 13 [121].
} 
nacechowaną pragmatyzmem, ostrożnością, rozwagą w działaniu, budującą odpowiednie relacje między terapeutą a pacjentem, niezaniedbującą metod mistycznych. Interesujące jest zalecenie Kadłubka dotyczące procesu badania ran. W tej kwestii Mistrz występuje przeciwko lekarzom uniwersyteckim, którzy na zasadzie funkcjonującego w medycynie europejskiej stereotypu, iż wykonują zawód ,arystokratyczny”, uważali, że nie przynosi im zaszczytu stykanie się z krwią i ropą, i w efekcie, bez bliższego badania, zalecali tu dietę oraz środki farmakologiczne ${ }^{21}$. Kadłubek stanowczo sprzeciwia się takim zaleceniom, dając wyraz swemu odmiennemu i jakże postępowemu stanowisku.

\section{Witelo (1230/1235-1275/1292)}

Urodził się prawdopodobnie w Legnicy jako syn niemieckiego kolonisty, który przybył na Śląsk z Turyngii, i miejscowej Polki ${ }^{22}$. Czuł się Polakiem, o czym świadczy zdanie z ostatniej księgi jego dzieła De perspectiva (O perspektywie): „In nostra terra, scilicet Polonia...” (W naszej ziemi, a mianowicie w Polsce). Kształcił się najpierw w szkole parafialnej, przy parafii św. Piotra w Legnicy, a następnie, tu pojawiają się już tylko przypuszczenia, w szkole katedralnej we Wrocławiu ${ }^{23}$. W latach pięćdziesiątych XII stulecia przebywał w Paryżu, gdzie poświęcił się studiom uniwersyteckim na wydziale artium. Jesienią 1262 roku udał się do Padwy i na tamtejszym uniwersytecie zapoznawał się z dekretami i dekretaliami. Czytał ze studentami teksty Arystotelesa i nauczał geometrii ${ }^{24}$. W 1268 roku Witelo uzyskał stopień magistra prawa kanonicznego, a następnie udał się na dwór papieski w Viterbo. Przebywał tam kilka lat, po czym, najpóźniej w 1274 r., opuścił Włochy udając się do Czech, gdzie przez krótki okres zajmował stanowisko kapelana króla Przemysła Ottokara II, po czym wrócił do Polski. W ostatnich latach swego

\footnotetext{
${ }^{21}$ Zob. szerzej: J. Jagla, Boska medycyna, s. 30.

${ }_{22}$ J. Burchardt, List Witelona do Ludwika we Lwówku Śląskim. Problematyka teoriopoznawcza, kosmologiczna i medyczna, Wrocław-Warszawa-Kraków-Gdańsk 1979, s. 26; w odniesieniu do datacji życia Witelona, w literaturze przedmiotu panują rozbieżne opinie, zob. przykładowo W. Wąsik, Historia filozofii polskiej, t. 1, Scholastyka, Renesans, Oświecenie, Warszawa 1958, s. 26.

${ }^{23}$ W. Wąsik, Historia filozofii polskiej, t. 1, s. 26, 27.

${ }^{24}$ J. Burchardt, List Witelona, s. 28.
} 
życia był kanonikiem kapituły katedry wrocławskiej. Zmarł przed 15 marca $1292 \mathrm{roku}^{25}$.

Swe życie spędził bardzo pracowicie. Oprócz wspomnianego dzieła De perspectica, napisał również: Scienta motuum caelestium (Naukę w obrotach ciat niebieskich), De philosophia naturali (O filozofii natury), Naturales animae passiones (Naturalne afekty duszy), De elementatis conclusionibus (O początkach wnioskowania). Traktaty te znane są jedynie z tytułów, dziś dysponujemy jedynie tekstami De perspectiva, De primaria causa poenitentiae (O najgłówniejszej przyczynie skruchy $)^{26}$ oraz De causa primaria paenitentiae in hominibus et de natura daemonum" (O pierwotnej przyczynie pokuty $w$ ludziach i o naturze demonów) ${ }^{27}$. Sławę europejską przyniosło mu dzieło $O$ perspektywie, nazywane popularnie „Optyką" ${ }^{28}$. Przez kilka wieków stanowiło ono podstawowe źródło informacji o budowie oka oraz fizycznych i matematycznych prawidłowościach rozchodzenia się i załamywania światła. Znali je tacy uczeni, jak Regiomontanus, Leonardo da Vinci, Mikołaj Kopernik i Jan Kepler ${ }^{29}$. Ten ostatni swój traktat z 1604 r. zatytułował nawet Ad Vitellionem Paralipomena, czyli Dodatki do Vittelona ${ }^{30}$.

Ze względu na temat niniejszych rozważań najistotniejszy okazuje się dla nas traktat Witelona $O$ pierwotnej przyczynie pokuty $w$ ludziach $i$ o naturze demonów, napisany przez niego w latach 1267-1268 ${ }^{31}$. Tekst ujęty jest w formie listu skierowanego do mistrza Ludwika z Lwówka Śląskiego. Już na wstępie autor zaznaczył, że metodą, jaką się posługuje, jest Tatio et experimentum, czyli rozum i doświadczenie ${ }^{32}$. W dalszej części traktatu Witelo deklarował, że jego celem nie jest występowanie przeciwko „zasadom świętej religii chrześcijańskiej”, która bada prawdę "metodą nienaturalną, prawdziwie boską i przez Boga objawioną”, ale dochodzenie do niej „metodą naturalną i możliwą "33. Potem przystąpił do rozważania problemu demonów, przyjmując, zgodnie z oficjalną nauką Kościoła, faktyczne ich istnie-

\footnotetext{
25 Tamże, s. 31, 32.

${ }^{26}$ W. Wąsik, Historia filozofii polskiej, t. 1, s. 27.

27 Tamże, s. 31.

${ }^{28}$ Omówienie treści tego dzieła, zob. A. Birkenmajer, Witelo najdawniejszy polski uczony, Katowice 1936, s. 21-28.

${ }^{29}$ Tamże, s. 29.

${ }^{30}$ Tamże, s. 10.

${ }^{31}$ J. Burchardt, List Witelona, s. 30, 34.

${ }^{32}$ P. Trzebuchowski, O poglądach medycznych Witelona ze Śląska, Wiadomości Lekarskie 1956, s. 183.

${ }^{33}$ Za W. Wąsik, Historia filozofii polskiej, t. 1, s. 29.
} 
nie $^{34}$, ale jego akceptacja takiego stanowiska nie była bezkrytyczna. Wysunął mianowicie tezę, że u podłoża wielu chorób psychicznych, tkwią różnorakie schorzenia organizmu. Stwierdził, że opary płynów ustrojowych zabarwiają mózg na skutek czego dochodzi do fałszywego postrzegania przez jednostkę otaczającego ją świata. Dochodzi do psucia mózgu i wyobcowania umysłu. Rozum traci swą władzę rozkazodawczą oraz kontrolną nad zmysłami, a do głosu dochodzi fantazja, która interpretuje chorobliwe zachowania umysłu jako uobecnianie się demonów, przyjmując złudzenia za „świat istniejący realnie" ${ }^{35}$. Witelo podkreśla również, że u podstaw zaburzeń w percepcji świata tkwi także nadmiernie rozbudowana wyobraźnia danej jednostki, która często dostrzega to, czego oczekuje. Zjawisko to przedstawia na przykładzie zachowania zakochanych, którzy są w stanie, na podstawie omamów wzrokowo-słuchowych, dostrzegać nieobecne osoby, obiekty ich miłości ${ }^{36}$.

Zaprezentowane podejście Witelona do chorób psychicznych mogło wpływać na kreowanie postaw lekarzy odnośnie do pacjentów objawiających zaburzenia w prawidłowej percepcji otaczającego ich świata. Uwalniało medycynę od konieczności zajmowania się problemem opanowania duszy przez demony. Chore psychicznie osoby w czasach Witelona, zgodnie z chrześcijańskim miłosierdziem, otaczano co prawda opieką i poddawano leczeniu za pomocą egzorcyzmów, ale równolegle, co nie było wcale rzadkością, znieważano jako opętanych przez diabła, izolowano w więzieniach, a nawet obwożono po jarmarkach jako swoistego rodzaju dziwadła. A już najgorszy spotykał je los, gdy zostały oskarżone o czary, co mogło skończyć się śmiercią na stosie ${ }^{37}$. Lekarze byli wówczas wzywani na proces jako rzeczoznawcy i los chorego spoczywał w ich ręku. To oni decydowali, czy u podłoża dziwnych zachowań jednostki stoją demony niepoddające się egzorcyzmom, czy też zachowania

\footnotetext{
34 Temat demonów, zob. Encyklopedia katolicka, t. 3, red. R. Łukaszyk, L. Bieńkowski, F. Gryglewicz, Lublin 1995, hasło: demonologia, s. 1166.

${ }^{35}$ J. Burchardt, List Witelona, s. 151; P. Trzebuchowski, O poglądach medycznych Witelona, przedstawia nieco zmienioną interpretację „Listu”, s. 184, 185.

${ }^{36} \mathrm{~J}$. Burchardt, List Witelona, s. 17; interesująco problem fantazji przedstawił J. Burchardt, Rola fantazji przy powstawaniu złudzeń wzrokowych wedle padewskiego listu Witelona $z$ r. 1268, AH i FM 2006, t. 69, nr 3-4, s. 117-127.

${ }^{37}$ Zob. szerzej Kronika medycyny, red. M. B. Michalik, s. 118, 119; W. Szumowski napisał: „Wśród osób palonych na stosie za rzekome czary było niewątpliwie sporo psychicznie chorych. [...] Często ginęły też na stosie jednostki umysłowo nierozwinięte, głupkowate, dziwaczne, mało wykształcone, te bowiem dawały się łatwo wpędzić w matnię krzyżowych pytań inkwizytorów"; także Historia medycyny filozoficznie ujęta, s. 297, 298; szczególnie J. Michelet, Czarownica, przeł. M. Kaliska, Warszawa 1961.
} 
te są skutkiem chorobowych zmian organizmu lub, na przykład, nadmiernie rozbudowanej wyobraźni ${ }^{38}$. Kierując się naukami Witelona, czyli ujmując chorobę w kategoriach naturalnych, pełniący takie funkcje medycy-rzeczoznawcy mogli ocalić wielu ludzi od niechybnej śmierci. Zajęcie przez takich lekarzy racjonalnej postawy, oprócz wiedzy fachowej, wymagało jeszcze odwagi, męstwa i bezkompromisowości w dążeniu do prawdy. W tym wypadku osobistym przykładem mógł świecić sam Witelon, bo głoszone przez niego tezy stały w jaskrawej sprzeczności z oficjalną nauką Kościoła, to zaś wymagało dużej odwagi. Zarówno swymi tezami, jak i postawą, mógł więc Witelon wpływać na postawy etyczne lekarzy. I z takiej perspektywy należy rozpatrywać jego wkład w rozwój etyki lekarskiej.

Trzeba jeszcze zauważyć, że opisane powyżej problemy należy odnieść również do stuleci po czasach Witelona, gdyż za jego życia procesy o czary oraz uległość demonom w Polsce jeszcze się nie zdarzały. Szaleństwo takich pseudoprocesów, tkwiące korzeniami w tragicznych aspektach kultury europejskiej, dopiero się na Zachodzie zaczynało ${ }^{39}$. W niczym nie umniejsza to jednak wkładu Witelona w kształtowanie postaw etycznych lekarzy wobec chorych psychicznie, ponieważ przedstawiony traktat, jako efekt pracy uczonego o europejskiej sławie, był długo i szeroko komentowany, co poświadczają przechowane aż do naszych czasów jego mnogie wersje, tak pełne, jak i skrócone ${ }^{40}$.

\section{Tomasz z Wrocławia (1297-1378)}

Urodził się w 1297 roku, a zmarł 24 września 1378 roku w opactwie św. Wincentego pod Wrocławiem. W kwestii miejsca jego urodzenia wśród historyków medycyny panują rozbieżne opinie. Mogła nim być Świdnica, Legnica albo Wrocław. Te same rozbieżności dotyczą warstwy społecznej, z jakiej Tomasz pochodził. Niektórzy utrzymują, że był synem kasztelana Przybysława we wsi Sadowel, przynależnego do Rawiczów. Inni dowodzą, że bardziej prawdopodobne jest pochodzenie mieszczańskie ${ }^{41}$. Po ukończeniu nauk, najpierw w szkole parafialnej, a następnie katedralnej, mając

\footnotetext{
${ }^{38}$ B. Seyda, Dzieje medycyny, s. 112.

${ }^{39}$ Zob. szerzej M. Pilaszek, Procesy o czary w Polsce w wiekach XV-XVIII, Kraków 2008; także W. Szumowski, Historia medycyny, s. 287-333.

${ }^{40}$ Zob. J. Burchardt, List Witelona, s. 36-54.

${ }^{41}$ J. H. Skalski, K. Wronecki, Tomasz $z$ Wrocławia, biskup tytularny Sarepty, [w:] Zasłużeni dla medycyny, red. J. H. Skalski, R. W. Gryglewski, Poznań 2009, s. 23, 25; zob. szerzej J. Bur-
} 
16 lat, otrzymał od zakonu o.o. Norbertanów stypendium umożliwiające kontynuowanie edukacji. Udał się za granicę, gdzie studiował w Montpellier, Padwie, Bolonii i Salerno, co znaczy, że poznał wszystkie ważniejsze uczelnie ówczesnej Europy. Edukacja ta trwała 17 lat, po którym to okresie powrócił do Wrocławia. Posiadał wówczas tytuł doktora dekretów i otaczała go chwała słynnego lekarza i uczonego. $Z$ tego względu, przez wiele lat pełnił funkcje lekarza piastowskich książąt śląskich, a jeden z nich, książę Henryk VI (1294-1335) powierzał mu często różne misje dyplomatyczne. Tomasz wyprawiał się więc do papieża Jana XXII (1316-1334), króla neapolitańskiego oraz hrabiego Prowansji, Roberta (1309-1343) ${ }^{42}$. Leczył m.in. króla czeskiego Jana Luksemburczyka, cesarza niemieckiego Karola IV i wymienionego wyżej papieża Jana XXII. W dowód znacznych zasług, w 1352 r., na wniosek biskupa wrocławskiego Przecława z Pogorzeli, papież Klemens VI, mianował go biskupem tytularnym Sarepty. Było to zaszczytne wyróżnienie, właśnie tam bowiem, zgodnie z biblijną tradycją, prorok Eliasz wskrzesił zmarłego chłopca. W momencie nadawania tej godności owo miasto, położone w Azji Mniejszej, znajdowało się jednak poza zasięgiem władzy papieskiej ${ }^{43}$.

Oprócz działalności na polu medycyny i dyplomacji Tomasz osiągnął znakomite sukcesy $\mathrm{w}$ nauce, utrwalone $\mathrm{w}$ szeregu traktatów. Wymienić tutaj można takie dzieła, jak: Alphabetum sive Collectorium, Regulae, De phlebotomia et de indiciis cruoris oraz Mihi competit. To ostatnie składa się z czterech części: Regimen sanitatis, Aggregatum medicinarum simplicium, Antidotarium i Practica medicinalis. Rozważania i uwagi na temat postawy lekarza, jak i sztuki lekarskiej zawarł w Regimen sanitatis (Traktat o higienie).

Już na wstępie Tomasz twierdzi, że to Bóg wszczepił naturze ludzkiej pragnienie wiedzy o tym, co jest pożyteczne, przyjemne, rzetelnie uczciwe i dlatego właśnie, wiedzę o utrzymywaniu zdrowia poprzez usuwanie szkodliwych dla niego odchyleń, należy traktować jako „dobro" ${ }^{44}$. W dalszej części traktatu autor przedstawia swą wizję należytego uprawiania sztuki medycznej. Omawia też czynniki konstytuujące postać wzorowego lekarza. W dotyczących tych kwestii fragmentach tekstu czytamy:

chardt, Higiena wedle Tomasza $z$ Wrocławia, Studia Copernicana, t. 34, Warszawa 1997, s. 8;

W. Lisowski, Ludzie zasługi niepospolitej, Warszawa 1983, s. 20.

${ }^{42} \mathrm{~J}$. Burchardt, Higiena wedle Tomasza, s. 8.

${ }^{43}$ J. H. Skalski, K. Wronecki, Tomasz z Wrocławia, [w:] Zasłużeni dla medycyny, s. 24.

${ }^{44}$ J. Burchardt, Higiena wedle Tomasza, s. 8. 
W zawodzie lekarskim wielkie trudności poznawcze oraz lęk, by nie narazić na niebezpieczeństwo znakomitych pacjentów, winny odstraszać lekkomyślnych i próżnych chciwców, zaś uczciwego lekarza powinna od tego lęku chronić poznana nauka oraz obserwacje doświadczonych i mądrych medyków minionych czasów.

Nikomu kto nie ukończył studiów lekarskich i nie posiada doświadczenia nie wolno mniemać, że leczy niezawodnie „mając na sobie strój zawodu i umiejętności praktyczne". Dotyczy to zwłaszcza terapii złożonych chorób wewnętrznych i rozmaitych przypadłości zróżnicowanej, złośliwej materii. Kto uzurpuje sobie, by wykonywać zawód lekarza, ale leczy wbrew zasadom sztuki medycznej, jest tylko chciwym oszustem i nieukiem, któremu powinno się zakazać praktyki.

Kto na podstawie jednego tylko doświadczenia usiłuje leczyć wszystkie choroby, tego niech akceptują pacjenci, którzy chcą być oszukani. Inni powinni się go wystrzegać.

Użyteczniejszy w wielu chorobach jest lekarz, doświadczony w sztuce lekarskiej, który osobiście przebrnął przez wiele prób. Ten bowiem lepiej od innych zna cierpienia i dogłębniej współczuje choremu.

O ile choroba jest uleczalna, pacjent jest posłuszny, a lekarz dysponuje odpowiednimi środkami, wiążącym założeniem jest jeszcze oczekiwanie, by terapia odbyła się według zasad sztuki medycznej.

Jeżeli lekarz „jednym ciągiem” leczy wielu pacjentów, to takie jego działanie jest mało bezpieczne. Bo choć budzi zaufanie u każdego chorego i jego sława rośnie, to jednak czas dzielony na wielu nie pozwala zająć się dostatecznie jak należy powierzonym mu chorym.

Wypytywanie otoczenia o sprawy poprzedzające chorobę i o obyczaje żywieniowe chorych daje lekarzowi więcej prawdy niż zaszczytu, bo co głupsi pytania te biorą za nieuctwo. Ale pomijanie anamnezy jest szkodliwe.

Chorego może leczyć jeden lekarz lub wielu. Nie ma niebezpieczeństwa dla chorego, jeżeli powierza się go wielu lekarzom, byleby za każdym razem sąd o sposobie leczenia był jednakowy. Gdy opinie lekarzy są sprzeczne, najczęściej pacjenta naraża się na niebezpieczeństwo. Leczenie przybiera doskonały kształt, gdy pacjenci nie biorą lekarzy za natrętów, obłudników, nieuków lub chciwców. [...]

W przypadkach chorób trudnych i wątpliwych podjąć się leczenia albo odmówić - na równi przynosi lekarzowi ujmę. Bezpieczniejszy jest lekarz nie podejmujący się takiej terapii, ale milszy choremu ten, kto - mimo wszystko leczyć próbuje. [...]

Kto lecząc chorych naraża się sam na chorobę, to dzieje się tak dlatego, że wielka jest jego miłość albo też jest butnym samochwałem. Sławny lekarz leczy tylko z miłości swych chorych. 
Tylko ten lekarz może chwalebnie podjąć się leczenia, którego nie można przymusić do tego, by pomógł ani też, gdy sam z własnej potrzeby o coś pacjenta błaga.

Gdy lekarz liczy się w terapii z pomysłami i uczuciami chorego, to jest to niebezpieczne nadużycie.

Jeżeli lekarz jest w rokowaniu rozważny, rozbudza ufność chorego i gotuje sobie chwałę. Ale lekarz wypowiadający nieroztropną prognozę nie tylko choremu zadaje uraz, ale i swą sztukę lekarską naraża na niezasłużoną szkodę" ${ }^{\prime 45}$.

Jak wynika z powyższego tekstu, Tomasz z Wrocławia stawiał lekarzowi bardzo wysokie wymagania etyczne. Przede wszystkim powinien on być wykształcony, bo wiedza zapewnia mu rozwagę, pewność w podejmowanych działaniach i skutkuje postawieniem prawidłowej diagnozy. Czynniki te przyczyniają się także do zbudowania u chorego zaufania. Inną cechą, jaką bezwzględnie powinien wyróżniać się lekarz, jest doświadczenie, które $\mathrm{w}$ połączeniu $\mathrm{z}$ wiedzą czyni go mistrzem w zawodzie. Ale pojęcie doświadczenia rozumie Tomasz bardzo szeroko. Zalicza do niego także osobiste przeżycia lekarza w zakresie przebytych chorób, bo to właśnie one umożliwiają współuczestnictwo w cierpieniach pacjenta (obarcza więc lekarza zdolnością do empatii).

Trzeba się w tym miejscu zgodzić, że zaprezentowany wzorzec lekarza cechuje nie tylko wymaganie mistrzostwa, ale wręcz zawodowego perfekcjonizmu.

Z dalszych fragmentów przytoczonego tekstu wynika, że Tomasz zaleca lekarzowi również pragmatyzm. Istotną kwestią zawsze staje się tu pożytek wynikający z poznania okoliczności, w jakich powstało dane schorzenie. Autor sugeruje, że taka sama diagnoza stawiana przez kilku lekarzy, może być nawet słuszna, jednak przestrzega, aby jeden lekarz nie sprawował opieki nad kilku chorymi równocześnie, ponieważ może to odbić się ujemnie na jakości leczenia. W innym miejscu omawia się okoliczności decydujące o sławie lekarza. Według Tomasza sława i chwała przedstawicieli tego zawodu jest ściśle uzależniona od faktu, czy dany lekarz jest w stanie trwać przy chorym, chociaż naraża przy tym swe zdrowie. Jako motywację takiej postawy wymienia Tomasz miłość (miłosierdzie) do chorego, a nie męstwo czy zuchwałość, zaznaczając, że postępek ów miłosierny powinien zaistnieć na warunkach dobrowolności, a nie przymusu. Dziś takie zachowanie ocenialibyśmy w kategoriach męstwa zawodowego. Ostatnią z poruszanych

\footnotetext{
${ }^{45}$ Przytoczono za J. Burchardt, Higiena wedle Tomasza, s. 9-11.
} 
w traktacie ważnych kwestii jest postawa lekarza w obliczu przypadków trudnych czy beznadziejnych. Tomasz nie udziela tutaj kategorycznej wskazówki, sugeruje tylko, że w takich okolicznościach zarówno zaniechanie leczenia, jak i jego podjęcie, nie jest dobrym rozwiązaniem.

Pomimo sławy, jaką się cieszył, w swej praktyce lekarskiej Tomasz zajmował się także leczeniem ludzi ubogich. Ofiarowywał wówczas medykamenty, na których zakup nie było ich stać ${ }^{46}$.

\section{Abstract \\ Polish Medical Ethics before the Founding Cracow Academy (Wincenty Kadłubek, Witelo, Thomas of Wrocław)}

The article contains historical discussion concerning the forming of the idea of medica ethics in Poland before founding the institutional, formal structures of power and supervision over the medical profession. It was quite early when the necessity of the prohibition of practice for those who are not professionals, who lack knowledge and skill was recognized. The sources of Polish medical ethics can be found in the views of doctors coming to Poland after accomplishing their medical studies. Together with the proper knowledge they must have learnt certain standards of moral attitudes and they also must have grafted them onto our ground. The propagation of ethical culture was also possible due to the activity of other scholars together with state and church dignitaries being in contact with the culture of Western Europe.

46 Tamże, s. 10. 